Ivan-Damir Anić, Ph.D.*

UDK 658.89-053.6(497.17)

Anita-Ciunova-Suleska, Ph.D.**

Preliminary paper

Edo Rajh, Ph.D.*

Prethodno priopćenje

\title{
DECISION-MAKING STYLES OF YOUNG-ADULT CONSUMERS IN THE REPUBLIC OF MACEDONIA
}

\begin{abstract}
The purpose of this research is to examine decision making styles and to test the Sproles and Kendall's (1986) CSI instrument (Consumer Style Inventory) among young-adult consumers in the Republic of Macedonia. It segments young-adult consumers by their decision-making styles and determines the differences among segments relative to their decision-making styles. The empirical analysis is based on data obtained from consumer survey. The data were analyzed using Cronbach alpha coefficients, exploratory factor analysis and k-means cluster analysis. Research results confirmed eight-factor model. Two homogeneous segments of consumers were identified: Economic consumers and Recreational consumers. Significant gender differences were found on four factors of consumer-decision making styles (brand consciousness, novelty-fashion consciousness, recreationalhedonistic consumer and habitual, brand-loyal consumer). Marketing strategies should be tailored to the specific characteristics of consumers in the Republic of Macedonia.
\end{abstract}

JEL Classification: M30, M31

Key words: Consumer decision-making styles, Consumer Style Inventory, Consumer segmentation, Gender differences, The Republic of Macedonia

\section{INTRODUCTION}

Researchers and marketers show a growing interest in the research of consumers' decision-making styles to understand how and why people shop. Sproles and Kendall (1986) define a consumer decision making style as a mental orientation characterizing a consumer's approach to making choices. This concept is important to marketing because it determines consumer behavior and is relevant for market segmentation (Sproles and Kendall, 1986; Walsh, Hennig-Thurau, Wayne-Mitchell and Wiedmann, 2001). Although decision-making styles have been examined in various cultural environments, the generalizability of Consumer Style Inventory (CSI) instrument has not been established yet (Lysonski, Durvasula and Zotos, 1996; Hanzaee and Aghasibeig, 2008; Yasin, 2009; Anić, Piri Rajh and Rajh, 2009; Walsh, Hennig-Thurau, Wayne-Mitchell and Wiedmann, 2001). Consumer Style Inventory (CSI) is a comprehensive instrument developed by Sproles and Kendall (1986) used for measuring consumer decision making styles. More research is needed to examine consumer decision making styles and to test CSI instrument in different countries. Having a reliable and valid instrument is a prerequisite for creating shopping orientation profile of consumers that can be used to guide marketing strategy.

The purpose of this research is to examine decision making styles and the applicability of Sproles and Kendall's CSI instrument among young-adult consumers in the Republic of Macedonia. The objectives of the paper are: (1) to assess the reliability and construct validity of CSI instrument in the Republic of Macedonia, (2) to segment young-adult consumers by

\footnotetext{
${ }^{*}$ Institute of Economics, Zagreb, Trg J. F. Kennedyja 7, 10000 Zagreb, Croatia, danic@eizg.hr

** University "Ss.Cyril and Methodius" Faculty of Economics - Skopje, Bul. Krste Misirkov bb, 1000 Skopje, Republic of Macedonia, anita@eccf.ukim.edu.mk

*** Institute of Economics, Zagreb, Trg J. F. Kennedyja 7, 10000 Zagreb, Croatia, erajh@eizg.hr
} 
their decision-making styles, (3) to determine differences among segments relative to their decision-making styles, and (4) to determine gender differences in decision-making styles among young-adult consumers in the Republic of Macedonia. Data collected by consumer survey were analyzed using Cronbach alpha coefficients, exploratory factor analysis and kmeans cluster analysis.

To address the issues described above, we conduct an empirical study which builds on the stream of research that attempts to test the generalizability of the consumer styles inventory (Sproles and Kendall CSI research, 1986; Lysonski, Durvasula and Zotos, 1996; Mitchell and Walsh, 2004; Anić, Piri Rajh and Rajh, 2009). There is no study on consumers' decision making styles in the Republic of Macedonia. Since the Republic of Macedonia belongs to the less developed transition countries with lower levels of income where the traditional way of life coexists with ongoing modernization, it is questionable whether the CSI instrument that was established for developed countries are also applicable in developing country. As we test the CSI instrument, we may refine the theory by findings from the environment of the Republic of Macedonia with respect to consumers' decision-making style segments and gender differences.

Several managerial implications might be derived from this study. Marketers might use the findings to segment consumers according to their decision-making styles, to target and position their products more effectively. International companies might use the findings of this study to tailor their marketing strategies to specific characteristics of consumers when entering the market of the Republic of Macedonia.

The paper starts with the theory of consumers' decision making styles. The methodology used is presented in section three, which is followed by research results in section four. Section five includes conclusions, limitations of the research, and future research directions.

\section{THEORY OF CONSUMERS’ DECISION MAKING STYLES}

Sproles (1985) and Sproles and Kendall (1986) conceptualized the Consumer Styles Inventory (CSI), which is an early attempt to systematically measure shopping orientations using decision-making orientations. One of the most important assumptions of this approach is that each individual consumer has a specific decision-making style resulting from a combination of their individual decision making dimensions. Originally, the instrument contained 50 items to measure general orientations towards shopping, and in 1986 Sproles and Kendall developed 40 items instrument, calling it the consumer style inventory (CSI). They validated eight different decision-making dimensions from a sample of U.S. high school students. The CSI dimensions are: (1) Perfectionism or high-quality consciousness characteristic that describes a perfectionist, high-quality conscious consumer who searches for the very best quality in products, and is not satisfied with the "good enough" product; (2) Brand consciousness - a characteristic identifying those consumers who buy more expensive, well-known national brands. They believe that a higher price means better quality, and prefer best selling advertised brands; (3) Novelty-fashion consciousness - characteristic indicating consumers who are fashion and novelty conscious, and seek out new things. For them it is important to be up-to-date with styles; (4) Recreational, hedonistic shopping consciousness - a characteristic identifying those consumers who find shopping pleasant and shops for the fun; (5) Price consciousness - a characteristic identifying those consumers who look for sale prices and are conscious of lower prices. They are concerned with getting the best value for their money, and are likely to be comparison shoppers; (6) Impulsiveness - a characteristic identifying those consumers who do not plan their shopping, and are unconcerned about how 
much they spend; (7) Confusion from over choice - a characteristic identifying those consumers who have difficulty making choices, and experience information overload; (8) Brand-loyal orientation towards consumption - a characteristic identifying those consumers who have favorite brands and stores. They stick with their brands and go shopping each time they shop.

Past research on CSI test the applicability of CSI instrument in various countries. Although, consumer decision-making style represents a relatively consistent pattern of cognitive and affective responses, national culture has been proven to impact significantly on individual values and attitudes (Hofstede, 1980), thus, culture is expected to have a significant influence on consumer decision-making style (Cheryl, Bennett and Hartel, 2005). There have been differences in applicability of CSI instrument across various environments, since some dimensions showed a poor reliability and need some modifications (Siu, Wang, Chang and Hui, 2001; Walsh, Hennig-Thurau, Wayne-Mitchell and Wiedmann, 2001; Mitchell and Walsh, 2004). However, there are studies that established elements for validity for eight characteristics of consumer style in several countries (Sproles and Kendall, 1986; Wesley, LeHew and Woodside, 2006; Anić, Piri Rajh and Rajh, 2009). Therefore, it might be expected that young-adult consumers in the Republic of Macedonia express eight decision making styles.

Other studies examine the potential of CSI for market segmentation purposes (Walsh, Hennig-Thurau, Wayne-Mitchell and Wiedmann, 2001; Akturan and Tezcan, 2007; Anić, Piri Rajh and Rajh, 2009). The study of Walsh, Hennig-Thurau, Wayne-Mitchell and Wiedmann (2001) identified the following meaningful and distinct decision-making groups: value oriented consumers, the demanding comparison shoppers, impulsive consumers, emotionally dominated consumers, brand-oriented and shopping enthusiastic consumers, fashion conscious consumers. Therefore, it might be expected that young-adult consumers in the Republic of Macedonia might be classified in different consumer segments according to decision-making styles.

There are also studies that seek to understand how gender affects consumers' approaches to decision making. Past research indicates males and females differ with respect to decision-making process and emotional expression in purchasing behavior. While men tend to be less involved in shopping than women, women like shopping and often have the primary responsibility for the supply of grocery goods (Underhill, 1999). Women tend to spend more time shopping, make more purchases and purchase a higher percentage of products on an unplanned basis, although the women's roles in households change so does their shopping behavior. One study on gender differences found only four common factors to both males and females, and five additional separate male and female factors (Mitchell and Walsh, 2004), so that it can be expected that male and female consumer decision-making styles vary in the sample of the Republic of Macedonia.

\section{METHODOLOGY}

Data on CSI dimensions were collected using survey administered to 304 undergraduate students at the Faculty of Economics in Skopje in 2010. As in most replications of the CSI (Mitchell and Walsh, 2004), student sample was used to demonstrate whether the CSI inventory can be applied to the Republic of Macedonia. Since young people are eager to consume, are conscious of their experience, they are valid consumers for this study (Sproles and Kendall, 1986). Sample profile is presented in Table 1. 
Table 1.

\begin{tabular}{|c|c|}
\hline \multicolumn{2}{|c|}{ Summary statistics on sampled consumers, N = 304} \\
\hline & \\
\hline Gender (\%) & \\
\hline Male & 32.9 \\
\hline Female & 67.1 \\
\hline Age (average years) & 20.4 \\
\hline
\end{tabular}

Items used in the questionnaire were taken from Sproles and Kendall (1986). The instrument contained 40 Likert-scaled items, ranging from one to five, where one equals „strongly disagree“ and five equals ,strongly agree“. The items used in this research are listed in Appendix 1. Cronbach alpha coefficients were calculated to quantify the scale reliabilities. For the second step the construct validity of the consumer styles was examined using exploratory factor analysis. Then, K-means cluster analysis was employed to develop consumer typology based on CSI, while the differences in CSI's between consumers' segments were analyzed using the analysis of variance (ANOVA). Consumer segments were identified and named based on mean scores on each CSI factor. ANOVA was used to test the gender differences in CSI dimensions.

\section{RESEARCH RESULTS \\ 3.1. Assessment of reliability and construct validity}

Reliability of scales was assessed using Cronbach alpha coefficients. Values of Cronbach alpha if deleted were calculated for each item. Items that decrease Cronbach alpha coefficients of respective scales were deleted from further analysis (i14, i18, i27, i31). Table 2 shows the results of reliability analysis.

Table 2.

Reliability assessment

\begin{tabular}{|c|c|}
\hline Items & Cronbach alphas if deleted \\
\hline \multicolumn{2}{|c|}{ Perfectionist, high-quality conscious consumer/Cronbach Alpha for subscale: 0.784} \\
\hline i1 & 0.762 \\
\hline i2 & 0.772 \\
\hline i3 & 0.757 \\
\hline $\mathrm{i4}$ & 0.733 \\
\hline i5 (r) & 0.741 \\
\hline i6 & 0.769 \\
\hline i7 (r) & 0.764 \\
\hline i8 (r) & 0.783 \\
\hline \multicolumn{2}{|c|}{ Brand conscious consumer/ Cronbach Alpha for subscale: 0.770} \\
\hline i9 & 0.698 \\
\hline $\mathrm{i10}$ & 0.709 \\
\hline i11 & 0.748 \\
\hline $\mathrm{i} 12$ & 0.721 \\
\hline $\mathrm{i13}$ & 0.751 \\
\hline i14 & 0.774 \\
\hline \multicolumn{2}{|c|}{ Novelty fashion conscious consumer/ Cronbach Alpha for subscale: 0.741} \\
\hline i15 & 0.674 \\
\hline i16 & 0.617 \\
\hline
\end{tabular}




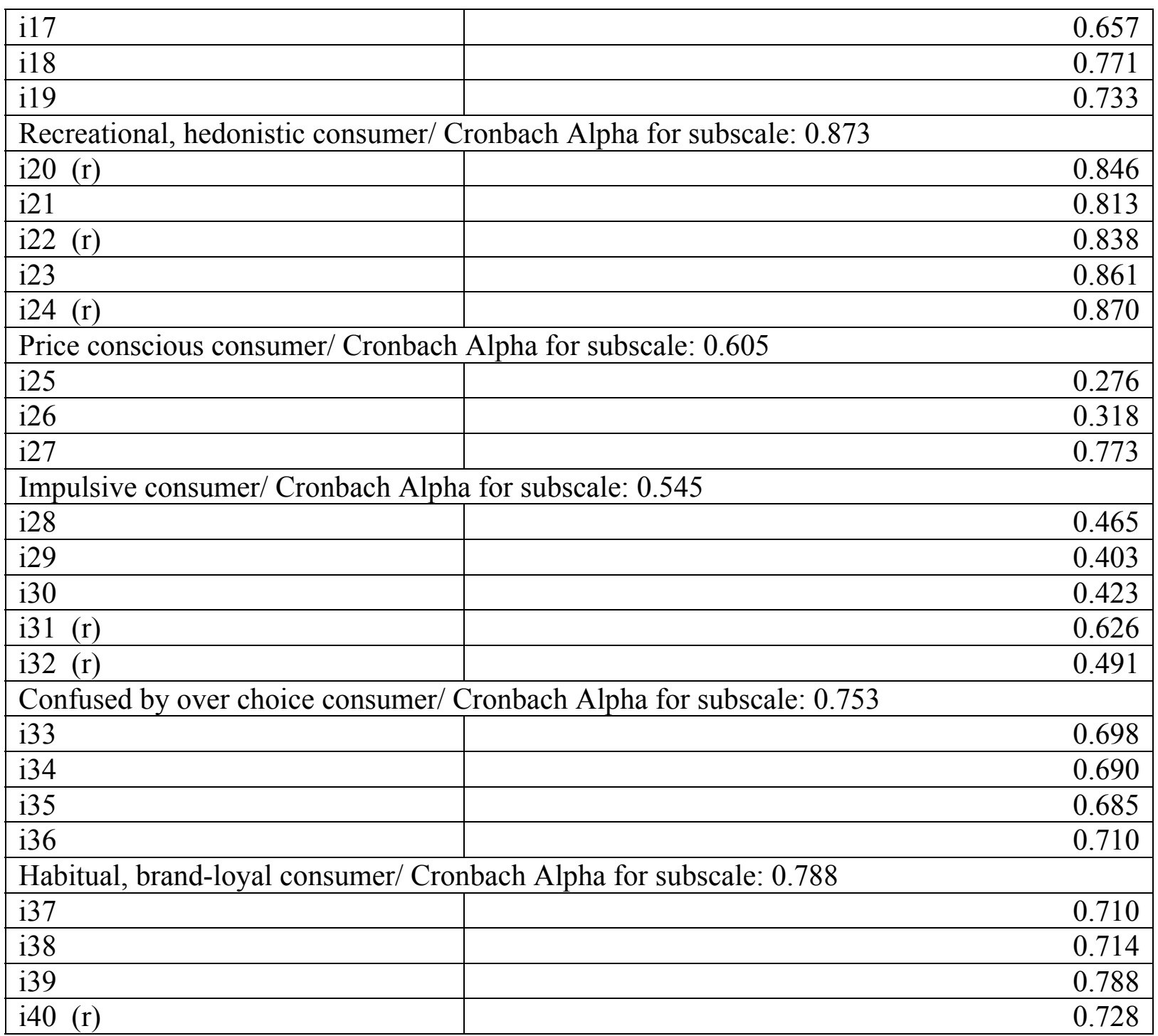

Note: " $r$ " denotes negative items that were recoded before the analysis.

Construct validity was assessed using exploratory factor analysis. First run of exploratory factor analysis indicated that there are five items that have low factor loading on respective factor and high factor loading on some other factor (i4, i5, i7, i8, i19). These five items were deleted from further analysis. Table 3 shows second run factor structure after varimax factor rotation. There were eight factors as conceptualized in the literature, with $63.0 \%$ of explained variance. The results of exploratory factor analysis indicate acceptable level of convergent and discriminant validity. 
Table 3.

Factor analysis results, factor loadings

\begin{tabular}{|c|c|c|c|c|c|c|c|c|}
\hline Items & Factor 1 & Factor 2 & Factor 3 & Factor 4 & Factor 5 & Factor 6 & Factor 7 & Factor 8 \\
\hline i1 & 0.145 & 0.095 & 0.041 & -0.066 & 0.156 & 0.724 & 0.234 & -0.056 \\
\hline i2 & -0.037 & 0.387 & -0.104 & -0.167 & 0.073 & 0.482 & -0.201 & 0.199 \\
\hline i3 & 0.103 & 0.117 & -0.044 & -0.023 & 0.100 & 0.740 & 0.131 & 0.139 \\
\hline i6 & -0.016 & 0.080 & -0.055 & -0.001 & 0.111 & 0.649 & 0.137 & 0.173 \\
\hline i9 & 0.600 & -0.004 & 0.051 & 0.100 & 0.226 & 0.332 & 0.198 & 0.249 \\
\hline i10 & 0.512 & 0.078 & 0.069 & 0.023 & 0.192 & 0.363 & 0.442 & 0.256 \\
\hline i11 & 0.786 & 0.165 & 0.004 & 0.045 & 0.128 & -0.024 & 0.041 & -0.055 \\
\hline $\mathrm{i} 12$ & 0.767 & 0.084 & -0.069 & -0.029 & 0.098 & 0.018 & 0.098 & 0.157 \\
\hline $\mathrm{i} 13$ & 0.476 & -0.109 & 0.102 & 0.054 & 0.093 & 0.198 & -0.028 & 0.328 \\
\hline i15 & 0.066 & 0.259 & 0.041 & 0.004 & 0.131 & 0.015 & 0.291 & 0.675 \\
\hline i16 & 0.119 & 0.384 & 0.060 & 0.058 & 0.009 & 0.081 & 0.157 & 0.755 \\
\hline i17 & 0.147 & 0.310 & 0.035 & 0.088 & 0.049 & 0.167 & 0.029 & 0.733 \\
\hline i20 & 0.065 & 0.789 & 0.018 & -0.071 & 0.089 & 0.019 & -0.001 & 0.192 \\
\hline i21 & 0.076 & 0.883 & 0.021 & 0.045 & 0.009 & 0.068 & -0.005 & 0.153 \\
\hline $\mathrm{i} 22$ & -0.001 & 0.844 & -0.024 & 0.063 & 0.058 & 0.063 & 0.110 & 0.070 \\
\hline i23 & 0.026 & 0.732 & -0.057 & 0.102 & -0.008 & 0.009 & -0.010 & 0.165 \\
\hline i24 & 0.126 & 0.671 & 0.031 & -0.129 & -0.036 & 0.203 & 0.207 & 0.168 \\
\hline$i 25$ & -0.049 & -0.064 & 0.055 & 0.035 & -0.084 & -0.083 & -0.866 & -0.052 \\
\hline i26 & -0.162 & -0.074 & 0.053 & 0.018 & -0.135 & -0.190 & -0.775 & -0.225 \\
\hline $\mathrm{i} 28$ & -0.028 & 0.137 & 0.308 & 0.568 & 0.043 & 0.042 & -0.183 & -0.253 \\
\hline i29 & -0.004 & -0.049 & -0.106 & 0.783 & -0.038 & 0.017 & -0.025 & 0.145 \\
\hline i30 & 0.128 & 0.038 & 0.061 & 0.733 & -0.085 & -0.153 & -0.055 & 0.053 \\
\hline i32 & -0.029 & 0.059 & 0.150 & 0.588 & 0.163 & -0.013 & 0.192 & 0.052 \\
\hline i33 & -0.010 & 0.047 & 0.739 & 0.073 & -0.056 & 0.028 & -0.011 & 0.022 \\
\hline i34 & 0.034 & 0.022 & 0.765 & 0.039 & -0.175 & 0.068 & -0.015 & 0.011 \\
\hline i35 & 0.088 & -0.031 & 0.761 & -0.006 & 0.019 & -0.069 & -0.086 & 0.014 \\
\hline i36 & -0.129 & -0.069 & 0.715 & 0.012 & 0.042 & -0.099 & -0.002 & 0.105 \\
\hline i37 & 0.162 & 0.116 & 0.025 & 0.001 & 0.765 & 0.218 & 0.185 & -0.020 \\
\hline i38 & 0.027 & 0.042 & 0.054 & 0.049 & 0.784 & 0.149 & 0.146 & 0.069 \\
\hline i39 & 0.126 & -0.087 & -0.180 & -0.004 & 0.690 & -0.045 & -0.086 & 0.217 \\
\hline $\mathrm{i} 40$ & 0.138 & 0.044 & -0.120 & -0.075 & 0.782 & 0.021 & 0.052 & -0.029 \\
\hline
\end{tabular}

As expected, the results of this study indicate that young adult consumers in the Republic of Macedonia express eight decision making styles. Those decision making styles are: (1) perfectionism or high-quality consciousness, (2) brand consciousness, (3) noveltyfashion consciousness, (4) recreational, hedonistic shopping consciousness, (5) price consciousness, (6) impulsiveness, (7) confusion with over choice, (8) brand-loyal consumption. This result is in line with other similar empirical research (Sproles and Kendall, 1986; Wesley, Le Hew and Woodside, 2006; Anić, Piri Rajh and Rajh, 2009).

\subsection{CSI Segments}

K-means cluster analysis was employed to classify consumers according to their decision making styles. Items mean values were calculated for each factor using only items that remained after the reliability and construct validity assessment. These mean values were taken as an input in k-means cluster analysis. K-means cluster analysis produced two 
homogeneous segments of consumers. Significant differences between consumers' segments were found for all consumers' decision making styles, except for confused by over choice style. As expected the young-adult consumers in the Republic of Macedonia might be classified in different consumer segments according to decision-making styles. This result is in line with other research, indicating that CSI instrument might be used for segmentation purposes (Anić, Piri Rajh and Rajh, 2009). The results of k-means cluster analysis are presented in Table 4.

Table 4.

K-means cluster results, $\mathrm{N}=\mathbf{3 0 4}$

\begin{tabular}{|l|c|c|c|c|}
\hline \multicolumn{1}{|c|}{ Decision making styles } & $\begin{array}{c}\text { Sample } \\
\text { average } \\
(\mathrm{N}=304)\end{array}$ & $\begin{array}{c}\text { Segment 1: } \\
\text { Economic } \\
\text { consumers } \\
(\mathrm{N}=169)\end{array}$ & $\begin{array}{c}\text { Segment 2: } \\
\text { Recreational } \\
\text { consumers } \\
(\mathrm{N}=135)\end{array}$ & $\begin{array}{c}\text { ANOVA } \\
\text { p value }\end{array}$ \\
\hline $\begin{array}{l}\text { 1. Perfectionist, high- } \\
\text { quality conscious consumer }\end{array}$ & 3.88 & 3.65 & 4.16 & 0.00 \\
\hline $\begin{array}{l}\text { 2. Brand conscious } \\
\text { consumer }\end{array}$ & 2.88 & 2.46 & 3.40 & 0.00 \\
\hline $\begin{array}{l}\text { 3. Novelty, fashion } \\
\text { conscious consumer }\end{array}$ & 3.54 & 2.98 & 4.23 & 0.00 \\
\hline $\begin{array}{l}\text { 4. Recreational, hedonistic } \\
\text { consumer }\end{array}$ & 3.82 & 3.40 & 4.35 & 0.00 \\
\hline 5. Price conscious consumer & 2.89 & 3.35 & 2.32 & 0.00 \\
\hline 6. Impulsive consumer & 2.79 & 2.76 & 2.84 & 0.42 \\
\hline $\begin{array}{l}\text { 7. Confused by over choice } \\
\text { consumer }\end{array}$ & 2.81 & 2.84 & 2.78 & 0.50 \\
\hline $\begin{array}{l}\text { 8. Habitual, brand-loyal } \\
\text { consumer }\end{array}$ & 3.42 & 3.09 & 3.83 & 0.00 \\
\hline
\end{tabular}

On average, young-adult consumers in the Republic of Macedonia express high tendency towards perfectionism and recreational and hedonistic shopping. At the same time they express lower tendency towards impulsive shopping. They seem to plan their shopping trips in advance. On average, young-adult consumers in the Republic of Macedonia are still not confused by over choice. This is maybe because there are still not a large numbers of different brands in the market from which consumers could choose while doing shopping. The average values of brand consciousness and brand loyalty for both segments can be explained by the fact that most of the brands and stores that are present in the market are not so much involved in building long-term relationships with customers i.e. they do not develop customer loyalty programs, and do not give rewards cards, club cards nor loyalty cards). Recreational shopper is more loyal to brand and store than the economic shopper.

The characteristics of identified two clusters were examined based on the cluster means. The following labels were developed: Segment 1: Economic consumers and Segment 2: Recreational consumers. Economic consumers are very price conscious and tend to shop around for the lowest price (Bellenger and Korgaonkar, 1980). At the same time, those consumers are more interested in functional benefits of the products, oriented towards solving externally generated consumption needs (Park, Jaworski and MacInnis, 1986). Economic consumers are the most interested in quality of the product. They enjoy less shopping than recreational consumers and express below average loyalty to store or a brand. In total, $56 \%$ of consumers in the survey were categorized as economic consumers. 
Recreational consumers enjoy shopping as a use of their time. In the total, $44 \%$ of consumers in the sample were categorized as recreational consumers. When choosing store, this consumer consider the quality of merchandise and variety of merchandise and prefer high quality products. This finding is in line with the study of Bellenger and Korgaonkar (1980). Their standards and expectations for products that buy are very high. This consumer tends to buy something new and is very fashion conscious. Recreational consumers are interested in newest fashion trends, while the economic segment is almost indifferent to fashion changes.

\subsection{Gender differences in CSI}

ANOVA was used to determine gender differences among young-adult consumers in their decisions-making styles. Results are presented in table 5.

Table 5.

\section{Gender differences in CSI, N = 304}

\begin{tabular}{|l|c|c|c|}
\hline \multicolumn{1}{|c|}{ Decision making styles } & $\begin{array}{c}\text { Male } \\
(\mathrm{N}=100)\end{array}$ & $\begin{array}{c}\text { Female } \\
(\mathrm{N}=204)\end{array}$ & $\begin{array}{c}\text { ANOVA } \\
\text { p value }\end{array}$ \\
\hline $\begin{array}{l}\text { 1. Perfectionist, high-quality conscious } \\
\text { consumer }\end{array}$ & 3.92 & 3.86 & 0.40 \\
\hline 2. Brand conscious consumer & 3.03 & 2.81 & 0.03 \\
\hline 3. Novelty, fashion conscious consumer & 3.22 & 3.69 & 0.00 \\
\hline 4. Recreational, hedonistic consumer & 3.22 & 4.12 & 0.00 \\
\hline 5. Price conscious consumer & 2.82 & 2.93 & 0.35 \\
\hline 6. Impulsive consumer & 2.76 & 2.81 & 0.57 \\
\hline 7. Confused by over choice consumer & 2.88 & 2.78 & 0.38 \\
\hline 8. Habitual, brand-loyal consumer & 3.58 & 3.34 & 0.02 \\
\hline
\end{tabular}

Our findings indicate that there were significant gender differences $(p<0.05)$ on four factors of consumer-decision making styles (brand consciouness, novelty-fashion consciousness, recreational-hedonistic consumer and habitual, brand-loyal consumer). As compared to male consumers, females appeared to be less brand conscious and less brand loyal, but more novelty and fashion conscious and more interested in hedonistic shopping behaviour. However, on the other four factors no significant differences $(p>0.05)$ in consumer decision styles between men and women were found. Those factors are: perfectionist consumer, price consciousness, impulsive consumer, and confused by overchoice consumer. Both male and female customers equally pay attention to quality, price, and variety of offered goods and behave in the same way regarding impulsivness in decision-making process. As expected, our study found statistically significant gender differences on four factors, which is in line with other research (Mitchell and Walsh, 2004). Female consumer behavior tends to be similar as indicated in Underhill's study (1999). Our study further indicates that male consumers became similar like female consumers among the young-adult consumers with respect to perfectionism, price consciousness, impulsiveness, and confused by over choice.

\section{CONCLUSIONS}

These papers assessed CSI instrument reliability and construct validity, and examined the potential of the CSI instrument for segmenting the markets in the Republic of Macedonia. Research results indicate that CSI instrument applied in the Republic of Macedonia show acceptable level of reliability, convergent and discriminant validity. Eight-factor model was confirmed, indicating that young adult consumers in the Republic of Macedonia express eight 
decision making styles. K-means cluster analysis produced two homogeneous segments of consumers: Economic consumers and Recreational consumers. The analysis of gender differences among young-adult consumers shows that significant gender differences $(p<0.05)$ exist on four factors of consumer-decision making styles (brand consciouness, noveltyfashion consciousness, recreational-hedonistic consumer and habitual, brand-loyal consumer). It might be concluded that CSI instrument is applicable, and might be used as a tool for segmenting and profiling the consumers in the Republic of Macedonia.

Several managerial implications follow from the findings of this study. This study shows that in the Republic of Macedonia managers might use CSI instrument for market segmentation purposes. Marketing strategies should be carefully designed and be tailored to the specific needs of identified consumer decision-making styles segments.

This study is limited by several factors that should be addressed in future research. The analysis "took a snapshot" of a sample in the Republic of Macedonia. This research was done on university students who have limited marketplace experience and are still learning their consumer styles. Thus, it may not be possible to generalize the results in this study to whole population in the Republic of Macedonia. To gain a better and more general overview of this research area, future studies may expand the sample to include adult populations in the Republic of Macedonia. As this research included a relatively small sample size, future researchers may also focus their efforts on obtaining a larger number of respondents. Research might further investigate the relationship between CSI and other demographic variables (such as age and income) in the Republic of Macedonia. Despite these limitations, the results of this paper offer useful findings and pose some valuable managerial implications and direction for further research.

\section{REFERENCES}

Akturan, U., Tezcan, N., (2007), "Profiling young adults: Decision-making styles of college students for apparel products", in: 6eme Journees Normandes de Reserche sur la Consommation: Societe et consommations, Groupe ESC Rouen, Rouen, 19-20 March, 2007.

Anić, I.-D., Piri Rajh, S., Rajh, E., (2009), "Stilovi odlučivanja potrošača: testiranje metodologije i profiliranje stilova u Hrvatskoj", in: Marketing as a Factor of Sustainable Development, Conference Proceedings, CROMAR, Ekonomski fakultet u Osijeku, Osijek, October 8-10, 2009, CD-ROM.

Bellenger, D.N., Korgaonkar, P.K., (1980), "Profiling the recreational shopper", Journal of Retailing, 56 (3): 77-92.

Cheryl, L., Bennett, R., Hartel, C.E.J., (2005), "Cross-cultural differences in consumer decision-making styles", Cross Cultural Management, 12 (3): 32-62.

Gönen, E., Özmete, E., (2006), "Decision-making styles of young Turkish consumers", Journal of the HEIA, 13 (1): 26-33.

Hanzaee, K.H., Aghasibeig, S., (2008), "Generation Y female and male decision-making styles in Iran: are they different?", International Review of Retail, Distribution \& Consumer Research, 18 (5): 521-537.

Hofstede, G., (1980), Culture's consequences: International differences in work-related value, (Beverley Hills, CA: Sage Publications).

Lysonski, S., Durvasula, S., Zotos, Y., (1996), "Consumer decision-making styles: A multicountry investigation", European Journal of Marketing, 30 (12): 10-21.

Mitchell, V.W., Walsh, G., (2004), "Gender differences in German consumer decisionmaking styles", Journal of Consumer Behavior, 3 (4): 331-346 
Park, C.W., Jaworski, B.J., Maclnnis, D.J., (1986), "Strategic Brand Concept-Image Management", Journal of Marketing, 50 (4): 135-145.

Siu, N.Y.M., Wang, C.C.L., Chang, L.M.K., Hui, A.S.Y., (2001), "Adapting Consumer Style Inventory to Chinese Consumers: A Confirmatory Factor Analysis Approach", Journal of International Consumer Marketing, 13 (2): 29-47.

Sproles GB., (1985), "From perfectionism to dadaism: measuring consumers' decision-making styles", in Proceedings American Council on Consumer Interest Conference, Columbus, $\mathrm{OH} ; 1985,79-85$.

Sproles, G.B., Kendall, E.L., (1986), "A methodology for profiling consumer decisionmaking styles", The Journal of Consumer Affairs, 20 (2): 67-79

Underhill, P., (1999), Why we buy: science of shopping, (Simon\&Schuster, New York).

Yasin, B., (2009), "The Role of Gender on Turkish Consumers' Decision-Making Styles", in Advances in Consumer Research - Asia-Pacific Conference Proceedings, 8: 301-308

Walsh, G., Hennig-Thurau, T., Wayne-Mitchell, V., Wiedmann, K.-P. (2001), "Consumers' decision-making style as a basis for market segmentation", Journal of Targeting, Measurement \& Analysis for Marketing, 10 (2): 117-131.

Wesley, S., LeHew, M., Woodside, A.G., (2006), “Consumer decision-making styles and mall shopping behavior: Building theory using exploratory data analysis and the comparative method", Journal of Business Research, 59 (5): 535-548. 
Appendix 1: Items used in research

\begin{tabular}{|c|c|}
\hline I1 & Getting very good quality is very important to me. \\
\hline $\mathrm{I} 2$ & When it comes to purchasing products, I try to get the very best or perfect choice. \\
\hline I3 & In general, i usually try to buy the best overall quality. \\
\hline $\mathrm{I} 4$ & I make special effort to choose the very best quality products. \\
\hline I5 & I really don't give my purchases much thought or care. \\
\hline I6 & My standards and expectations for products I buy are very high. \\
\hline $\mathrm{I} 7$ & I shop quickly, buying the first product or brand I find that seems good enough. \\
\hline I8 & A product doesn't have to be perfect, or the best, to satisfy me. \\
\hline I9 & The well-known national brands are best for me. \\
\hline $\mathrm{I} 10$ & The more expensive brands are usually my choices. \\
\hline $\mathrm{I} 11$ & The higher the price of a product, the better its quality. \\
\hline $\mathrm{I} 12$ & Nice department and specialty stores offer me the best products. \\
\hline $\mathrm{I} 13$ & I prefer buying the best-selling brands. \\
\hline $\mathrm{I} 14$ & The most advertised brands are usually very good choices. \\
\hline I15. & I usually have one or more outfits of the very newest style. \\
\hline $\mathrm{I} 16$ & I keep my wardrobe up-to-date with the changing fashions. \\
\hline $\mathrm{I} 17$ & Fashionable, attractive styling is very important to me. \\
\hline $\mathrm{I} 18$ & To get variety, I shop different stores and choose different brands. \\
\hline I19 & It's fun to buy something new and exciting. \\
\hline $\mathrm{I} 20$ & Shopping is not a pleasant activity to me. \\
\hline $\mathrm{I} 21$ & Going shopping is one of the enjoyable activities of my life. \\
\hline $\mathrm{I} 22$ & Shopping the stores wastes my time. \\
\hline $\mathrm{I} 23$ & I enjoy shopping just for the fun of it. \\
\hline $\mathrm{I} 24$ & I make my shopping trips fast. \\
\hline $\mathrm{I} 25$ & I buy as much as possible at sale prices. \\
\hline $\mathrm{I} 26$ & The lower price products are usually my choice. \\
\hline $\mathrm{I} 27$ & I look carefully to find the best value for the money. \\
\hline $\mathrm{I} 28$ & I should plan my shopping more carefully than I do. \\
\hline $\mathrm{I} 29$ & I am impulsive when purchasing. \\
\hline $\mathrm{I} 30$ & Often I make careless purchases i later wish I had not. \\
\hline I31. & I take the time to shop carefully for best buys. \\
\hline I32. & I carefully watch how much I spend. \\
\hline I33. & There are so many brands to choose from that often I feel confused. \\
\hline I34. & Sometimes it's hard to choose which stores to shop. \\
\hline $\mathrm{I} 35$ & The more I learn about products, the harder it seems to choose the best. \\
\hline $\mathrm{I} 36$ & All the information I get on different products confuses me. \\
\hline $\mathrm{I} 37$ & I have favorite brands I buy over and over. \\
\hline $\mathrm{I} 38$ & Once I find a product or brand I like, I stick with it. \\
\hline I39 & I go to the same stores each time I shop. \\
\hline $\mathrm{I} 40$ & I change brands I buy regularly. \\
\hline
\end{tabular}




\section{STILOVI ODLUČIVANJA MLADIH POTROŠA С̆A U REPUBLICI MAKEDONIJI}

\section{SA}

Svrha ovog rada je istražiti stilove odlučivanja i testirali CSI ljestvicu koju su razvili Sproles $i$ Kendall (1986) na uzorku mladih potrošača u Republici Makedoniji. Također je izvršena segmentacija ispitanika i utvrđene su razlike među potrošačima s obzirom na njihov stil odlučivanja. Empirijska analiza temelji se na podacima koji su prikupljeni anketnim istraživanjem. Podaci su analizirani izračunom Cronbach alfa koeficijenata, primjenom eksplorativne faktorske analize, k-means klaster analize. Rezultati istraživanja pokazuju da postoji osam različitih, homogenih faktora stilova odlučivanja. Klaster analizom ispitanici su segmentirani u dva homogena segmenta s obzirom na iskazane stilove odlučivanja: ekonomični potrošači i rekreacijski potrošači. Također su potvrđene razlike između spolova na četiri faktora: sklonost marki, sklonost novitetima $i$ modi, sklonost hedonizmu i sklonost kupnji iz navike. Vodeći računa o rezultatima istraživanje menadžeri bi trebali prilagoditi svoje marketinške strategije specifičnostima makedonskog tržišta.

Ključne riječi: Stilovi odlučivanja potrošača, CSI instrument, segmentacija tržišta, razlike u spolu, Republika Makedonija 